\title{
Metastatic Thymoma with Good's Syndrome Mimicking Bronchiectasis
}

\author{
Nurdan KOKTURK ${ }^{1}$, Asiye KANBAY ${ }^{1}$, Cuneyt KURUL ${ }^{2}$, Nalan AKYUREK ${ }^{3}$, Leyla MEMIS ${ }^{3}$, \\ Sedat DEMIRCAN ${ }^{2}$, Haluk TURKTAS ${ }^{1}$ \\ ${ }^{1}$ Gazi University Faculty of Medicine, Department of Pulmonary Medicine \\ ${ }^{2}$ Gazi University Faculty of Medicine, Department of Thoracic Surgery \\ ${ }^{3}$ Gazi University Faculty of Medicine, Department of Pathology, Ankara, TURKEY
}

\begin{abstract}
Thymomas are mysterious tumors commonly have unpredictable behaviors and may be associated with several paraneoplastic conditions including Good's syndrome. We reported a patient with a history of thymoma who presented with centrilobuler parenchymal lung nodules and recurrent sinopulmonary infections. The nodules were found to be thymoma metastasis which persisted in the lungs for 3 years. The diagnosis of Good's syndrome was established in consistence with recurrent infections and progressive hypogammaglobulinemia.
\end{abstract}

Keywords: Thymoma metastasis, Good's syndrome, Amyloidosis

\section{ÖZET}

\section{Bronşektaziyi Taklit Eden metastatik Timoma ve Good's Sendromu}

Timoma, Good's Sendromu gibi humoral ve/veya hücresel immun yetmezliğe neden olan paraneoplastik sendromlarla birlikte seyreden zor tanınabilen tümördür. Good's Sendromu hipogammaglobulinemi ve sık tekrarlayan sinopulmoner enfeksiyonlar ile karakterizedir. Bu olgu sunusu, akciğere metastaz yapmış ve tedavisiz kalmış olmasına rağmen en az 3 yıllık sağkalımı tamamlamış olan ve sık tekrarlayan enfeksiyonları hatalı bir şekilde yalnızca bronşektaziye bağlanmış bulunan timoma ve GS tanısı konmuş bir hastayı tanımlamaktadır.

Anahtar Kelimeler: Timoma metastazı, Good's Sendromu, Amiloidoz 


\section{INTRODUCTION}

Thymomas are mysterious tumors that are presented with various paraneoplastic syndromes. Herein, a patient with thymoma, $40 \%$ have one or more paraneoplastic autoimmune condition, myasthenia gravis being the most common. Other uncommon syndromes are pure red cell aplasia, hypogammaglobulinemia, limbic encephalitis, myocarditis, thyroiditis, etc. Herein, we present a patient with a history of thymoma who experienced recurrent sinopulmonary infections and developed progressive hypogammaglobulinemia. He was found to have pulmonary metastases of thymoma and was eventually diagnosed with Good's Syndrome.

\section{CASE REPORT}

A 47-year old male patient was admitted to our institution in October 2003 with a history of frequent episodes of coughing, sputum production, high fever, sinusitis and dyspnea. He had experienced seven attacks of respiratory infections last year. $\mathrm{He}$ had been diagnosed with myasthenia gravis in 1998. One year later of initial diagnosis, a mediastinal mass consistent with thymoma had been discovered and thymectomy had been performed. The histological diagnosis had been predominantly cortical type of thymomas. The tumor had been staged as Stage III according to the Masaoka classification. He had received 50 Gy radiotherapy following surgery. He had experienced myasthenic crisis at the end of the radiation therapy. Since then he had been experiencing frequent exacerbations of upper and lower respiratory infections with high amount of sputum production. One year after thymectomy, thoracic computerized tomography (CT) showed occasional ectatic bronchi and micronodules in lower lobes of both lungs (Figure $1 \mathrm{a}, \mathrm{b}$ ). The respiratory infections were attributed to bronchiectasis. At that time, total immunoglobulin levels were found to be normal except slightly lower level of IgA. In the present admission, a thoracic $\mathrm{CT}$ revealed multiple centrilobuler parenchymal micronodules particularly dominating at lower lobes of both lungs (Figure $1 \mathrm{c}, \mathrm{d})$. Physical examination was unremarkable except for low grade fever $\left(38^{\circ} \mathrm{C}\right)$ and bilateral coarse crackles heard in the lung bases with auscultation. Laboratory data revealed haemoglobin level of $14.9 \mathrm{~g} / \mathrm{dl}$, white blood cell count of $16400 / \mathrm{mm}^{3}$, erythrocyte sedimentation rate of $36 \mathrm{~mm} /$ hour, albumin level of $2.9 \mathrm{~g} / \mathrm{dl}$, and total protein level of $4.5 \mathrm{~g} / \mathrm{dl}$. Urine analysis revealed proteinuria (6 $\mathrm{g} /$ day). Duodenal biopsy displayed AA type amyloidosis. Sputum cultures yielded Haemophilus influenza and Pseudomonas aeruginosa several times. No acid fast resistant bacilli were grown in any samples. Paranasal sinus CT revealed maxillary sinusitis. Immotile cilia syndrome was ruled out by examination of nasal mucosal biopsy on electron microscopy. Serum alpha-1 antitrypsin level and the sweat chloride test by iontophoresis were normal. Bronchoalveolar lavage and transbronchial biopsy were non-diagnostic. The patient underwent open lung biopsy. The parenchymal nodules seen on CT were found to be thymoma metastasis (Figure 2). The histological type of tumor was identical with primary lesion. With the probability of thymoma associated Good's Syndrome, serum immunoglobulin levels were measured and showed low level of Ig G [438 mg/dl (normal range: 690-1618)] and slightly low level of IgA [62.6 mg/dl (normal range: 68-375)]. Flow cytometric analysis demonstrated reduced level of CD20(+) cells (8\% of total lymphocytes) with a normal CD4/CD8 ratio (2.4/1). These findings were consistent with Good's syndrome. Fifteen days after surgery, his clinical condition deteriorated. He had myasthenic crisis induced by a pulmonary infection. After two-months of hospitalization in pulmonary intensive care unit, the patient died due to sepsis.

\section{DISCUSSION}

Thymomas are rare tumors that represent $0.2-1.5 \%$ of all malignancies. ${ }^{1}$ Although most of the thymomas are limited within a capsule and do not infiltrate adjacent tissues, they are potentially invasive and should be treated as a malignant disease due to unpredictable tumor behaviour. ${ }^{1,2}$ Tumor stage is the single factor that has a proven impact on survival. ${ }^{3}$ Stage III and IV diseases, which represent invasive thymoma, have worse prognosis with 5-year actuarial survival rates of $\% 67$ and $\% 50$, respectively. ${ }^{3}$ Chemotherapy should be added to surgical resection and radiotherapy in Stage IV patients. ${ }^{4}$ The recurrence rate for invasive thymoma is about $30 \%$ at a mean of 5.5 year after the initial resection. ${ }^{5}$ 

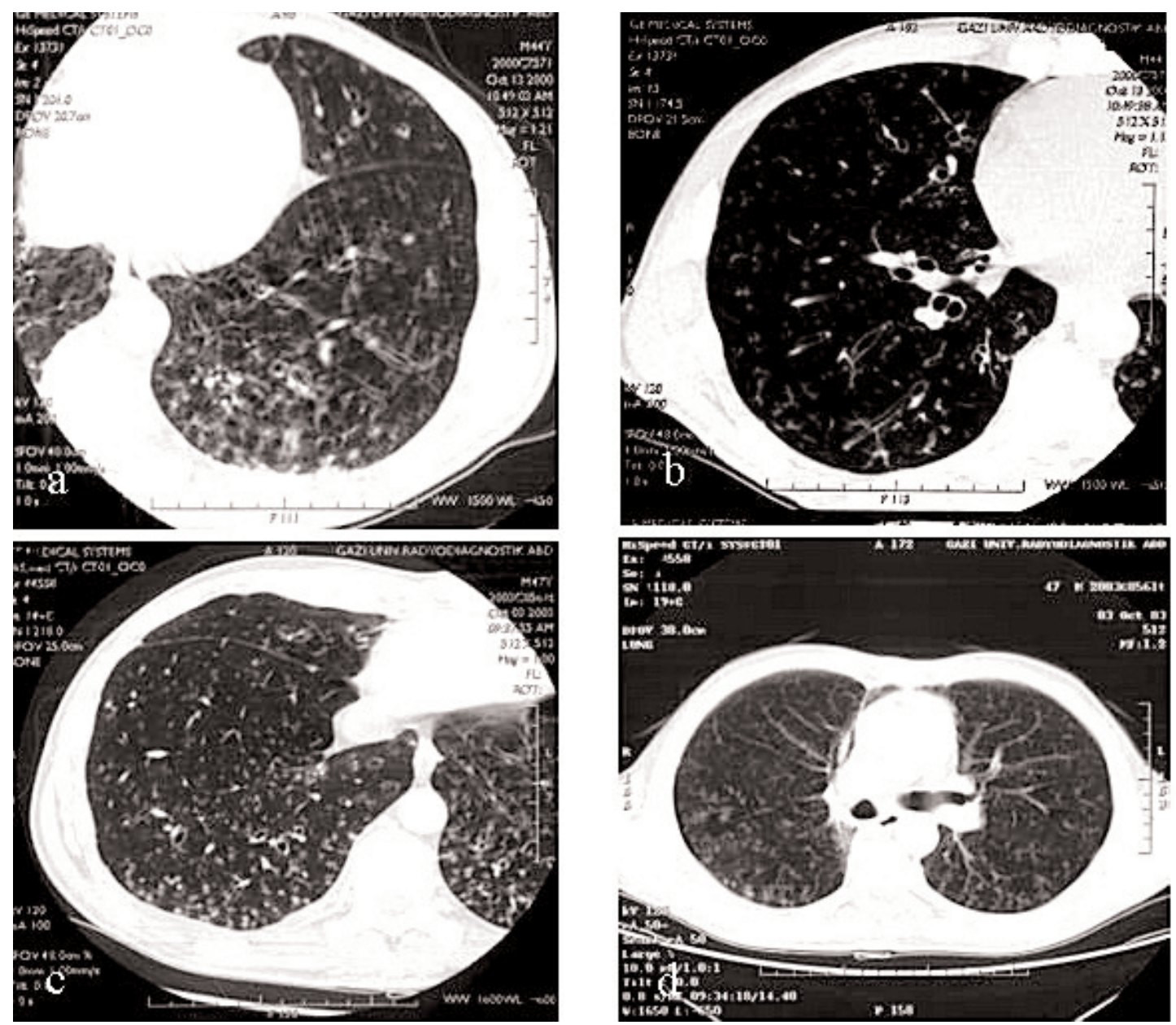

Figure $1 \mathbf{a}$, b. HRCT slides show some ectatic bronchi associated with hazy nodules

Figure $1 \mathbf{c}, \mathbf{d}$. Evident nodules present in the lower lobes bilaterally

The presented case has several unusual aspects. The patient had undiagnosed and therefore untreated pulmonary metastases persisting for 3 years. Although the radiological pattern of the nodules did not suggest tumor spread, open lung biopsy proved that those nodules were thymoma metastasis. This is an extraordinarily long survival for a stage IV untreated thymoma patient. Because of the rarity of advanced thymomas, no large-scale chemotherapeutic clinical trial has ever been conducted but the longest survival ever reported was about 4.3 to 5 years with several chemotherapeutics.,

Good's syndrome occurs in $7-10 \%$ of all thymomas. It is manifested by hypogammaglobulinemia, reduced or absent B cells, recurrent sinopulmonary infections caused by encapsulated microorganisms accompanied with opportunistic viral and fungal infections. ${ }^{6}$ Bronchiectasis can be found in the pati- ents with Good's Syndrome. It is more often associated with noninvasive thymoma unlike the presented case. ${ }^{5,6}$ The etiology and pathogenesis of the disease are unknown. ${ }^{6}$ Our patient had a history of recurrent sinopulmonary infections mostly secondary to Haemophilus influenzae and Streptococcus pneumoniae. The serum levels of total immunogammaglobulins were found to be initially normal except for slightly low IgA level. However, on follow up, IgG and IgA levels decreased. Importantly, if there is a suspicion of immunodeficiency, repeated investigations may be required because many cases with progressive immunodeficiency have been reported. ${ }^{6}$

Amyloidosis has been occasionally reported in association with acquired hypogammaglobulinemia. Although the pathogenesis is not understood completely, continuous chronic infection seems to be a 


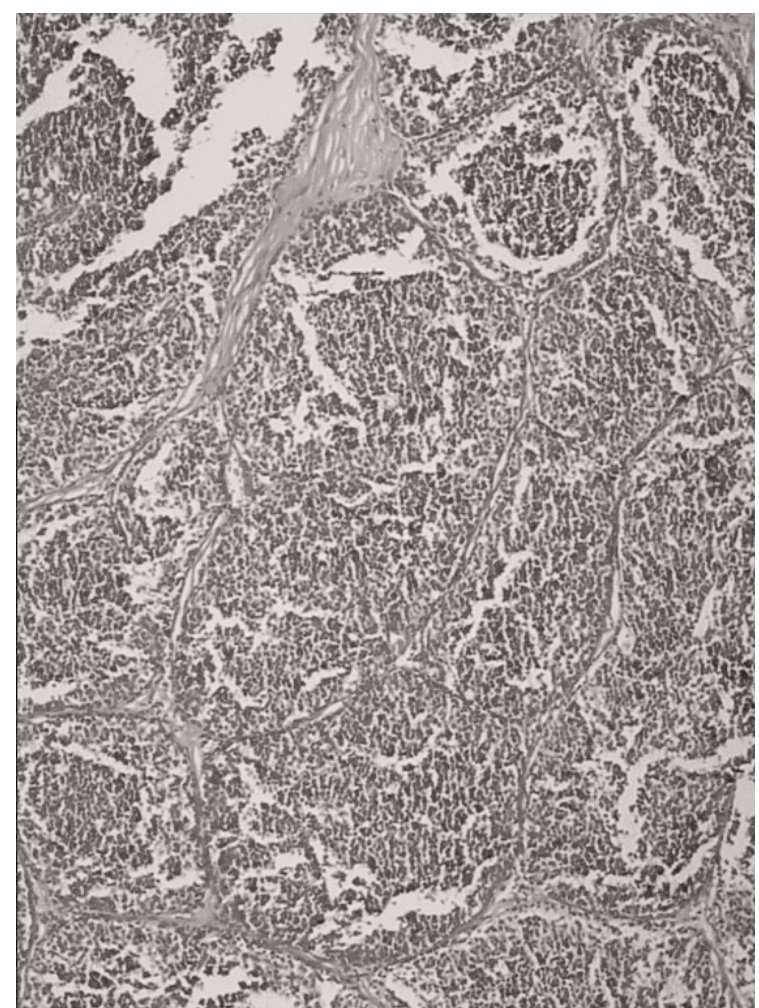

Figure 2. Type B1 thymoma, composed of a preponderance of small stromal lymphocytes. The epithelial cells are recognized by their pale round nuclei. (HE, X100)

triggering factor for the deposition of amyloid in different tissues. ${ }^{7}$ Amyloidosis developed in our patient because of inadequate treatment of hypogammaglobulinemia and related infections for three years. The association of amyloidosis, hypogammaglobulinemia and thymoma was first described by Conn et al. in their postmortem study of a patient with thymoma, amyloidosis and hypogammaglobulinemia. ${ }^{8}$ Our observation is the second in the literature showing the possible association between amyloidosis and Good's syndrome. Amyloidosis may precede hypogammaglobulinemia and it may be considered as an additional manifestation of Good's syndrome. ${ }^{8}$ Moreover, amyloidosis and subsequent proteinuria may augment hypogamaglobulinemia via renal loss, further complicating the situation.

This report emphasizes that thymomas may have unpredictable courses and even metastastatic thymomas may be associated with a long-term survival. In patients with a history of thymoma, para- neoplastic syndromes should be considered in differential diagnosis of newly emerged clinical situations. Additionally, diagnosis of a paraneoplastic syndrome on follow-up may be a harbinger of persistent or recurrent thymoma. Secondly, hypoglobulinemia may not appear in the initial course of Good's syndrome. Therefore repeat laboratory testing including immunoglobulin levels may be required in highly suspected cases.

\section{REFERENCES}

1. Schmidt-Wolf IG, Rockstroh JK, Schüller H, et al. Malignant Thymoma: Current status of classification and multimodality treatment. Ann Hematol 82: 69-76, 2003.

2. Okumura M, Ohta M, Tateyama $\mathrm{H}$, et al. The World Health Organization histologic classification system reflects the oncological behaviour of thymoma: A clinical study of 273 patients. Cancer 94: 624-32, 2002.

3. Chan JK. Tumors of the lymphoreticular system, including spleen and thymus. In: Fletcher CD editor. Diagnostic histopathology of tumors. London: Churchill Livingstone; 2001: 1270-85.

4. Lara PN. Malignant thymoma: current status and future directions. Tumour Review. Cancer Treat Rev 26: 127-131, 2000.

5. Park HS, Shin DM, Lee JS, et al. Thymoma. A Retrospective Study Of 87 Cases. Cancer 73: 2491-2498, 1994.

6. Kelleher P, Misbah SA. What is Good's syndrome? Immunological abnormalities in patients with thymoma. J Clin Pathol 56: 12-16, 2003.

7. Kotilainen P, Vuori K, Kainulainen L, et al. Systemic amyloidosis in a patient with hypogammaglobulinemia. J Inter Med 240: 103-106, 1996.

8. Conn HO, Quintiliani R. Severe diarrhea controlled by gamma globulin in a patient with agammaglobulinemia, amyloidosis, and thymoma. Ann Intern Med 65: 528-541, 1966.

\section{Correspondence}

Dr. Asiye KANBAY

Alpaslan Mah.

Alpaslan Apt. No: 25/14

Melikgazi

Kayseri / TURKEY

Tel: (+90.352) 2239753

E-mail: kanbaydr@yahoo.com 